\title{
0894. Time course of VILI development: a CT scan study
}

\author{
C Chiurazzi ${ }^{*}$, M Gotti ${ }^{1}$, M Amini ${ }^{1}$, C Rovati ${ }^{1}$, I Algieri ${ }^{1}$, M Brioni ${ }^{1}$, A Cammaroto ${ }^{1}$, C Bacile di Castiglione ${ }^{1}$, K Nikolla $^{1}$ \\ , C Montaruli', S Luoni ${ }^{1}$, B Comini ${ }^{1}$, G Rossignoli ${ }^{1}$, G Conte ${ }^{1}$, T Langer ${ }^{1}$, M Cressoni ${ }^{1}$, L Gattinoni ${ }^{1,2}$ \\ From ESICM LIVES 2014 \\ Barcelona, Spain. 27 September - 1 October 2014
}

\section{Introduction}

Mechanical Ventilation at high tidal volumes and pressures induces in lung oedema which is undistinguishable from ARDS. It is possible that pleura, bronchi and vessels act as a natural stress raiser playing as local stress multipliers. [1]

\section{Objectives}

To study the development of VILI with CT scan and determine where and when the first lesions appear and to follow their development in time.

\section{Methods}

Piglets were instrumented and ventilated with TV of corresponding to a strain $(\mathrm{TV} / \mathrm{FRC})>2.5$. The whole study was performed in an animal CT scan facilities equipped as an ICU. Every three hours a CT scan was performed and data on respiratory mechanics were collected. CT scans were analysed and lesions were defined as clearly defined regions of poorly/not inflated tissue $(-500 /+100 \mathrm{HU})$ with a minimal diameter of $6 \mathrm{~mm}$ non present in the previous CT scan image. Lung weight was computed from the CT scan data.

\section{Results}

We studied 11 swine $(22 \pm 5 \mathrm{~kg}), 5$ healthy and 6 with basal densities which did not regain inflation after a recruitment manoeuvre. As shown in Figure 1 most the CT scan lesions were subpleural. The first CT scan lesions appeared after a median of 7 hours [4.5-12] in healthy pigs and after a median of 9 hours [6.5-11.5] in diseased ones $(\mathrm{p}=0.88$ healthy vs diseased) while changes in lung mechanics developed after 20 [13 - 23] hours ( $p=0.04$ vs time of development of CT scan lesions) and oxygenation impairment, defined as $\mathrm{PaO} 2 \mathrm{FiO} 2<200$, after 25 [14 - 36] hours ( $\mathrm{p}=0.003$ vs time of development of CT scan lesions) while widespread lung oedema defined as presence of infiltrations in all lung fields at CT scan imaging developed after 18 [12 - 32] hours ( $p=0.02$ vs time of development of CT scan lesions).

\section{Conclusions}

Oxygenation and respiratory mechanics impairment is evident when relevant lung oedema develops. Most of the first $\mathrm{CT}$ scan lesions are located in lung regions which act as stress raisers and precede alterations in gas exchange and respiratory mechanics. 

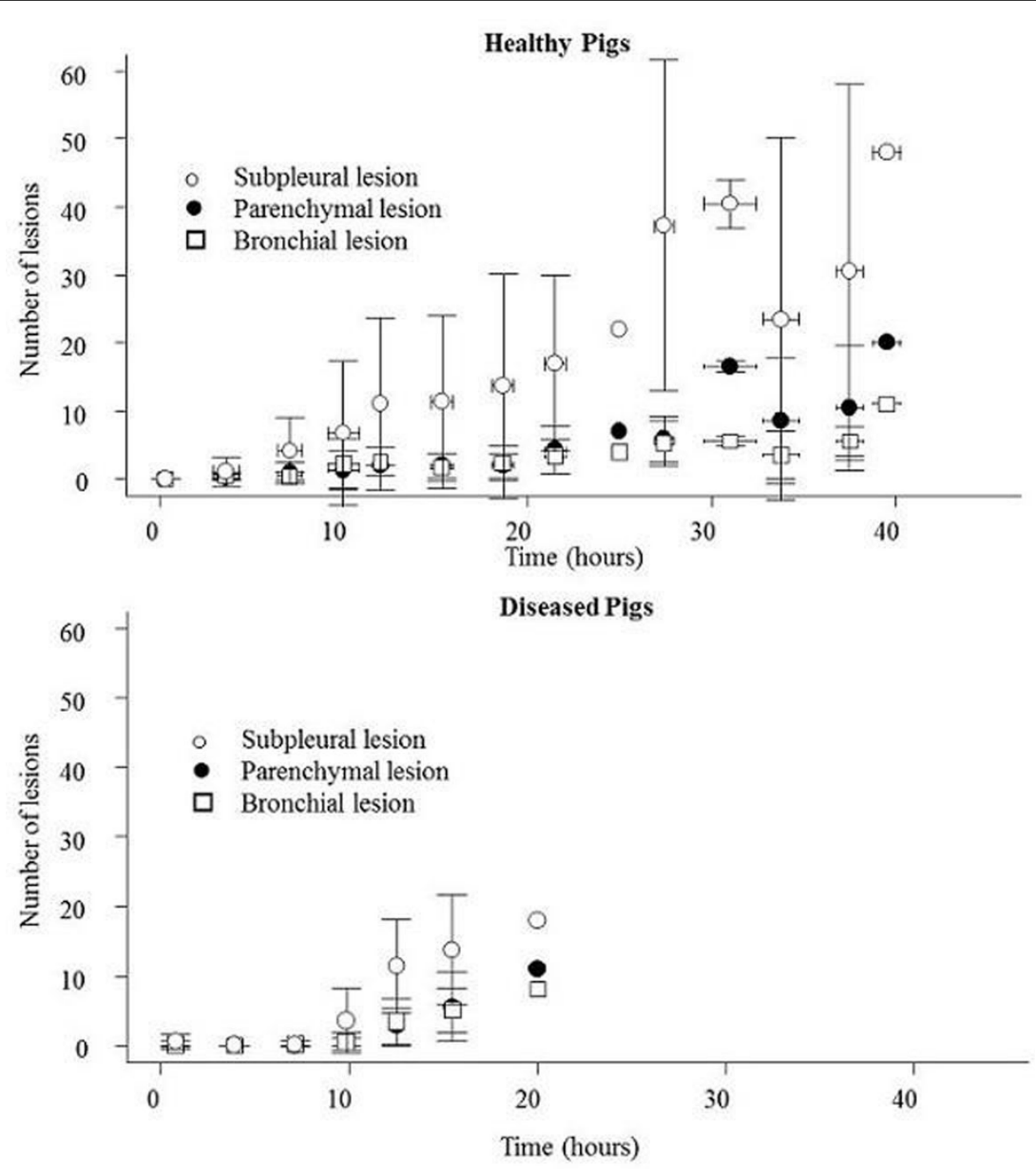

Figure 1 VILI Lesion Time Course.

\section{Grant acknowledgment}

ESICM Bernard Drager Award 2012 to M.C.

\section{Authors' details}

${ }^{1}$ Università degli Studi di Milano, Dipartimento di Fisiopatologia Medica e dei Trapianti, Milano, Italy. ${ }^{2}$ Fondazione IRCCS Ca' Granda - Ospedale

Maggiore Policlinico, Milano, Italy.

Published: 26 September 2014

\section{Reference}

1. Cressoni M, Cadringher P, Chiurazzi C, Amini M, Gallazzi E, Marino A, Brioni M, Carlesso E, Chiumello D, Quintel M, Bugedo G, Gattinoni L: Lung inhomogeneity in patients with acute respiratory distress syndrome. Am J Respir Crit Care Med 2014, 189(2):149-158.

doi:10.1186/2197-425X-2-S1-O20

Cite this article as: Chiurazzi et al:: 0894. Time course of VILI

development: a CT scan study. Intensive Care Medicine Experimental 2014 2(Suppl 1):O20.

\section{Submit your manuscript to a SpringerOpen ${ }^{\circ}$ journal and benefit from:}

- Convenient online submission

- Rigorous peer review

- Immediate publication on acceptance

- Open access: articles freely available online

- High visibility within the field

- Retaining the copyright to your article

Submit your next manuscript at $>$ springeropen.com 